\title{
John's gospel and the Johannine church: A mirror of events within a text or/and a window on events within a church
}

\author{
HA Lombard
}

\begin{abstract}
John's gospel and the Johannine church: A mirror of events within a text or/and a window on events within a church.

This paper investigates the problem of an alleged Johannine church/ school. The hermeneutical paradigms and results of two mainline exegetical methods are assessed, namely the historico-critical method and literary criticism (a textimmanent procedure). Their respective approaches of using the text of John's Gospel (JG) as a window and as a mirror are correlated.

An analysis of the narrator's commentary (footnotes, asides) furnished important conclusions. They are that a referential correlation exists between the worlds within and outside the text. The direction of reference runs from the textexternal to the textinternal worlds. Furthermore, the pragmatics of JG as a religio-historical text justifies the assumption that the readers/church within and outside the text are to be identified as ambivalent entities consisting of both Jewish and Hellenistic elements.
\end{abstract}

\section{JOHN'S GOSPEL AT THE FOCAL POINT OF REFLECTION ON METHODOLOGY}

A survey of paradigms for understanding, exposition and interpretation of the New Testament and John's gospel (hereafter abbreviated as ' $J G$ ') is not necessary in discussions with well-informed readers. In academic circles one assumes that there is competency regarding the history and development of exegetical methods and their application to texts.

One must emphasise, however, that the present situation of technocracy, cosmic threats, socio-political problems and focus on events and

\footnotetext{
* An abridged and revised edition of inaugural lecture as professor in New Testament studies at the Faculty of Theology of the University of South Africa on 30 Sept 1986.
} 
function of communication, has promoted functional, apocalyptic, sociological and textpragmatic approaches respectively. When it comes to an assessment of the legitimacy of methods and their application, JG in particular stands at the focal point. Major contributions to reflection on methodology and reports on research have been made by $\mathrm{R}$ Kysar (1975), H Thyen (1979), T Onuki (1982), J D G Dunn (1983), J Becker (1982 and 1986) and F P Neirynck \& F van Segbroeck (1984).

Important tendencies in research, indicated by these scholars are as follows:

(a) Onuki (1982: 163ff) draws our attention to the onesidedness of historical and historico-critical approaches. He advocates a literarysociological analysis of JG 'auf dem Wege zur Methodenintegration'. Furthermore he continues to contribute to research by reflecting on hermeneutical paradigms, text theory and textpragmatics.

(b) Dunn (1983: 309-39) focuses on the process of formation of JG. He contends that any further investigation of JG should be directed at scrutinising the extent to which the distinctive development and adaptation of early traditions were made to suit the needs of a specific Johannine church.

(c) Neirynck \& Van Segbroeck (1984: 211-17) list a total of 125 titles on JG during the years 1980-84. These publications furnish the research results of methodology and content with respect to JG.

(d) Becker (1986: 1-79) places JG in the centre of a 'Streit um Methoden' (1986: 1f). His survey of research on JG (1982 and 1986) lists a total of 141 titles. He also identifies a 'Taxonomie der methodischen Schritte' and maintains that no method can be neutral or be applied neutrally because any method breathes the spirit and context of its designer. The same can be said for the text. It shows an interaction which points in three directions, namely, backwards (relation between text and its sociological background), sidewards (the relationship and roles of characters within the world of the text) and forwards (relationship to the original and all other readers). In the past there was an overemphasis on the interaction backwards and this was done at the cost of adequate attention to the sidewards function (the analysis and interaction of events within the text) and the interaction forwards, in the sense of pragmatics of the text.

It has now become clear that an integration of methods should take place. This was advocated during an international symposium on philosophy of science held at Lovain University in 1978-79. Georg 
Strecker also pleads for a continuation of reflection on methodology, because the results of research on JG still contain many unsubstantiated hypotheses (see Festschrift für Wilhelm Schneemelcher 1984).

In South-African circles Bernard Lategan (1984: 1-17) has joined • these ranks and presented a thorough investigation on hermeneutics.

\section{STATING THE PROBLEM}

It goes without saying that the results of research should be coordinated and that further investigation on methodology should be sustained.

The angle of approach of this paper is the quest regarding the existence of the Johannine church/school and the light which experts on JG have shed on the problem. The vital question is whether it is feasible and legitimate to utilise JG as a source in describing the Johannine church. Or should we only refer to church/readers within the world of the text? In other words, are methods of reconstructing an actual Johannine church from JG legitimate?

The ultimate methodological issue at stake is whether one should use the text of JG as a WINDOW through which a church is perceived outside the text, or as a MIRROR in which a church is observed within the world of the text of JG.

This paper investigates the possibility that both these perspectives are offered by the text.

\section{THE CHOICE OF A MODEL OF UNDERSTANDING JG AND THE JOHANNINE CHURCH (NAMELY A HERMENEUTICAL PARADIGM)}

Every hermeneutical paradigm has a philosophical basis which, in turn, has a particular worldview (Weltanschauung). With reference to such paradigms, R Kysar (1975) has reported on the history of research in the Johannine field and has identified various approaches.

Exponents of the conventional grammatico-historical and historicocritical methods have utilised JG as a window through which they have looked at aspects of the Johannine problems, such as the character, function and circumstances of the Johannine church (see Krieger 1964: 3ff; Petersen 1978: 19). The meaning of JG is deduced and reconstructed on the basis of the relationship of the JG and its message to the history 
of a circle of real readers. Thus the value of the text lies beyond the window, namely in what the reader perceives about the 'history' of Jesus' ministry and the milieu and function of the Johannine church.

This paradigm is rejected by advocates of literary criticism. They have a different concept of the nature and intention of the text and consider that its primary intention is directed at a circle of readers within the text and not outside. Consequently, these scholars maintain that we cannot describe a real Johannine church from recourse to JG. They contend that the text of this gospel envisages and addresses a reader and a world within the text. Therefore, the text functions as a mirror and not as a window (see Krieger 1964: 4f; Beardslee 1970: 13f). In this approach the intention and meaning of the text lie in the architecture and contents of the whole text and the event of communication with the reader within the text. The omnipresent narrator in the text guides the readers in the textual interior into the narrated world of the text. The text tells this textinternal reader about characters, the characterisation of characters, the narrator/author's viewpoint (focalisation) of the story (the historical frame of reference of the narrative and narrated characters), about the roles of the various actants in the plot of the drama and about the conflicts (see Jakobson 1960: 353; Bal 1978: 33; Rimmon-Kenan 1983: 8; Culpepper 1983; Gräbe 1986: 151ff).

The basic concept of literary-critical paradigms is obviously that of communication between text and reader. In this event of communication the main character is the NARRATOR within the text. He conveys the perspective of the implied author to the reader within the text. $\mathrm{He}$ also sends out signals which create expectations, distance between and intimacy with the reader and which guide him/her to identify with the protagonist of the story (see Culpepper 1983: 4; Van Luxemburg, et al 1983: 156f). As far as the pragmatics of the text is concerned, the narrator intends to persuade the reader to accept other viewpoints. The reader must believe in what is narrated to him/her and he/she is manipulated to modify his/her own perception of the real world and to accept the perception of the narrator/author (see Ricoeur 1971: 536f; Dornisch 1975: 20; Fish 1980: 72; Vorster 1984: 150f).

According to the theory underlying literary criticism, a textual world and elusive 'paper readers' are created within the text, while the main event in this textual world is the communication within and by the text. This approach does not exclude historical exegesis, but it has to enter into dialogue with it and its exponents.

What is of importance here, is to note that with a literary-critical 
approach, the question of a Johannine church is being looked at textimmanently. In this procedure the possibilities and limitations of a text are critically explored and the narrative act and story (history of the events referred to) are analysed in order to reconstruct a church within the text of JG. The text, therefore, serves as a mirror of events within the text. Here we can only talk of implied, intended and ideal(-ised) readers, namely a Johannine church within the text of JG (see Jakobson 1960: 353f; Culpepper 1983: 6ff; Vorster 1985: 5).

When we scrutinise theories of literary criticism, we learn that texts have to do with two basis categories of readers, namely implied readers within texts and real readers outside the text. The relationship between these two types of readers is investigated below (see Prince 1971: 117-22; Iser 1974; 1978: 34f; Rabinowitz 1977: 121-41; Sternberg 1978: 256ff; Segers 1980; Suleiman 1980; Vorster 1985: 2-25; Van Aarde 1985: 45-62).

\section{IN SEARCH OF A JOHANNINE CHURCH WITHIN THE TEXT OF JG}

\subsection{Capita selecta from JG}

While in search of a reader/church within JG, the assumption has been made that the character and identity of an intratextual reader can be deduced implicitly and explicitly from an analysis of the commentary (i e footnotes) by the author/narrator. The commentary clearly indicates what the original reader either knew, or did not know, but should have known. The comments were made for the sake of a communication event and a process of persuasion within the text.

This commentary was originally made by the narrator, every time he purposely interrupted the flow of the narrative to change to a different mode or tense. These comments are also known as 'asides', 'footnotes' and 'the whispering wizard of the imperfect tense' (see Tenney 1960: 350f; Sternberg 1978: 1, 256; O'Rourke 1979: 210-19; Culpepper 1983: 16).

The narrator figures as a well-informed, omniscient and omnipresent personality who informs the reader of concealed and profound issues a kind of inside informer! He provides his information implicitly and explicitly. The implicit type of commentary is given by utilising literary techniques such as irony, misunderstandings which are cleared, enigma, symbols, et cetera. The explicit commentaries are spelled out in 
explanations, interpretation, judgment, general pronouncements and direct sayings. These commentaries are also retrospective and proleptic (see Booth 1961: 74f, 151ff; Abrams 1979: 566ff; Chatman 1978: 254; Genette 1980: 186ff; Culpepper 1983: 16f).

From the perspective of textpragmatics and communication, my analysis of JG has brought two hundred and three such footnotes to the fore. Of these, fifty-nine were identified by Tenney, fifty by O'Rourke and another two by Culpepper. These are distributed throughout the whole gospel, excluding the farewell discourses in John 13: 1-17:26, although many of the footnotes correlate with the main themes of the discourses.

These footnotes also function as bearers of the plot-development in the narrative and draw the reader's attention to some of the dramatic moments of the narrated events.

\subsection{Results of analytical survey}

The results of the analysis are as follows:

1. Translation of foreign words: seven footnotes. See John 1: 39, 42, 43; 9: 7; 19: 13, 17; 20: 16 .

2. Indications of localities, time and events: fifty footnotes. See John 1: 28, 35, 40, 44; 2 : 1-2, 12, 13, 23; 3: 22-23; 4: 3, 5-6, 27, $43,45-46 ; 5: 1-2,9 ; 6: 1,3-4,15,16-17,22,23,24,59 ; 7: 1-2,9,14$, 37; $8: 1-2,20 ; 9: 14 ; 10: 22-23,40 ; 11: 18,19-20,28,30,38,55 ; 12$ : 1,$12 ; 13: 1,2 ; 18: 1 ; 19: 14,41 ; 20: 1,19 ; 21: 1,4,19$.

3. Stipulation and explanation of national and religious customs: twelve footnotes.

See John 2: 6; 3: 25; 4: 9, 27; 5: 16, 18; 9: 14, 16; 19:31, 39, 40, 42.

4. Allusions to the author: two footnotes.

See John 19: 35; 21: 24.

5. Reminiscences of disciples about words of Jesus or about characters within the narrative: three footnotes.

See John 2: 17, 22; 12: 14-16.

6. Explanatory commentary on events concerning the characters of the narrative and their conduct: thirty nine footnotes.

See John 1: 7-8, 19, 24; $2: 9 ; 3: 23-24 ; 4: 4,8-9 ; 5: 3-4,16,18 ; 6: 2$, $10,18,41,52 ; 7: 1,5,12-18 ; 8: 6,9 ; 9: 14,22-23 ; 10: 6 ; 11: 30-31$, $51-52,53-54 ; 12: 3,6,37-43 ; 13: 28-29 ; 18: 28,32 ; 19: 24,36-37$; 20: $9,19,30-31 ; 21: 7,8$. 
7. Discussion and summary of events and issues: nineteen footnotes. See John $2: 11 ; 4: 39-41,54 ; 6: 10,13,22 ; 7: 43-44 ; 8: 30,59 ; 10: 19$, $39-42 ; 11: 45 ; 12: 9-11,18-19 ; 19: 20 ; 20: 30-31 ; 21: 11,14,25$.

8. Identification of characters within the narrative: thirty-one footnotes.

See John $1: 6,20-23,24,41,45 ; 3: 1 ; 4: 46 ; 6: 8,71 ; 7: 50 ; 11: 1-2$, 16,$49 ; 12: 4,21 ; 13: 2,23 ; 18: 2,10,13-14,15-16,40 ; 19: 38,39 ; 19$ : $25-26 ; 20: 2,3,8,24 ; 21: 2,7$.

9. Knowledge of Jesus, the main character, and insight into his thoughts and intentions: thirty-five footnotes.

See John 1: $14,38,44 ; 2: 11,21,23-25 ; 4: 1-2,6,44 ; 5: 6,13 ; 6: 5,6$, $15,61,64 ; 7: 10,30,39 ; 8: 20,27 ; 11: 5-7,12-13,33,38 ; 12: 16-17$; 13: $1,3,11,21 ; 18: 4,9 ; 19: 28 ; 21: 19,23$.

10. General theological discussions on events and sayings: five footnotes.

See John $1: 9-13 ; 3: 16-21,31-36 ; 20: 9,30-31$.

\subsection{Interpretation of results regarding footnotes}

In analysing and interpreting the footnotes, I am interested in a particular perspective only, namely to ascertain what indications these footnotes provide for identifying the character of a Johannine church within the text of JG. This concerns the question of the identity of the readers who were addressed, envisaged, implied and constituted by the events of communication of the text. Footnotes having no bearing on these details have been excluded.

\subsubsection{Footnotes relating to the translation of foreign words}

Five of the seven footnotes which translate or explain foreign words are translations from Hebrew/Aramaic into Greek, while in two instances a Greek name has been transformed into a descriptive Hebrew equivalent.

This phenomenon indicates that the narrator/author wished to inform his original readers that certain localities and persons within the narrated world of the text had significant Hebrew names. The translation from the Hebrew into Greek is aimed at transmitting the meaning that these terms had for the reader with a knowledge of Hebrew, to the Greek-speaking reader with no such knowledge. Therefore it must be assumed that the reader within the text was not familiar with these localities and names and their significance. This fact thus called for the translation and its explanation. 
There is also a hypothesis that there was an original Hebrew/Aramaic text which was translated into Greek and that the footnote translations are vestiges of such an original.

We come to the conclusion, therefore, that these translations were meant for the implied reader who was Greek-speaking and who was not acquainted with the Hebrew milieu in Palestine, which forms the frame of reference for the narrated story.

\subsubsection{Footnotes relating to indications of localities, time and events}

There are fifty footnotes in this category. They comprise indicators of localities (German: 'Ortdeixis') as well as indicators of time (German: 'Zeitdeixis') (See Crossan 1983: 4f; Phillips 1983: 30-34).

The footnotes relating to localities are indicators and descriptions of topographical and geographical nature. The indicators relating to time refer to the time of the saying of the narrative, that is, 'temps du discours', and to the actual time of the narrated events, that is, 'temps de 1'histoire' (see Benveniste 1966: 193f; Todorov 1972: $5 f$ sv 'Temps').

The former category is indicated by terms such as 'then', 'after', et cetera, and it describes the relationship between the narrator and the implied reader. The latter category is indicated by terms such as 'the next day', 'eight days later', 'the first day of the week', et cetera. It describes the relationship between the narrated characters as seen in a temporal perspective. This illuminates the course of the narrated events.

The analysis of the fifty footnotes points to a circle of readers who were familiar neither with the localities of the narrated world, nor with the course of time of the narrated events. In these markers (indicators), the focalisation (point of view) of the narrator with regard to his readers, comes prominently to the fore. The most salient aspect of this point of view is the narrator's perspective of the controversy between Jesus and his disciples on the one hand, and the actants in their roles as antagonists on the other (see Jn 1: 28; 6:41; 7: 1; 20: 19).

\subsubsection{Footnotes relating to the stipulation and explanation of national and religious customs}

An analysis of the twelve footnotes shows that the readers are informed of the existence and significance of certain Jewish customs, because they are probably unfamiliar with them. The readers need this information so as to understand Jesus' actions, and the narrator uses this information to persuade the readers to identify with Jesus. Conse- 
quently, the exclusive purpose and function of these footnotes are to promote the event of communication within the text and to create a positive response to Jesus' actions.

As far as the Johannine church is concerned, these footnotes reveal that the implied readers of JG were not Jews or Jewish proselytes. They were target groups which the narrator attempted to persuade to understand Jesus and to identify with him.

\subsubsection{Footnotes relating to allusions to the author}

These two footnotes are not addressed exclusively to the reader within the text. They make a statement to any reader that a certain disciple reported on and witnessed to Jesus' actions.

\subsubsection{Footnotes relating to the disciples' reminiscences of words of Jesus or of characters within the narrative}

In this category only one footnote is relevant, namely John 12: 14-16. This is a report on a discussion between the narrator and his readers. An appeal is made to them based on their familiarity with prophetic traditions of the Jews and with the Old Testament (such as Zch 9: 9, also Zph 3: 16 and Is 40: 9). This reference serves as comment on Jesus' role as king and provides its theological content. The narrator modifies the prophetic words as spelled out in the Septuagint and he places Jesus' actions in the context of Jewish apocalyptic expectations.

These footnotes change our concept of the image of the church within the text of JG up until this stage. This complicates the matter, since the church is no longer seen as being unfamiliar with the Jewish world and traditions of Jewry. On the contrary, it is assumed that the readers are familiar with Jewish prophetic traditions. If this were not the case, they would neither have understood nor received the message about Jesus as apocalyptic Messiah and their identification with Jesus would have been ruled out.

\subsubsection{Footnotes relating to explanatory commentary on events concerning the characters of the narrative and their conduct.}

These footnotes deal with characters, customs, insights and localities. The footnotes in this category which are relevant to our investigation, function on the level which G A Phillips (1983: 31, 36f) labels 'Rededeixis', that is markers of modality. They describe the attitude and the relationship of the characters within the narrative vis-á-vis the sayings of the narrative. 
Twenty-seven of these footnotes contain significant indications of the church within the text and the following come to our notice:

(a) The readers are strongly urged to identify with Jesus.

(b) The antagonists of the narrative are the Jews, Pharisees, scribes, chief priests, Jesus' brothers and Judas Iscariot. The readers are required to distance themselves from these antagonists (15 footnotes).

(c) The markers of locality refer to places in Palestine and a topography familiar to the reader.

(d) Footnotes which explain Jewish customs, presuppose familiarity with these customs and traditions (see Jn $5: 3-4,16 ; 8: 6 ; 9: 14 ; 11$ : $53 ; 12: 43-47 ; 18: 28,32 ; 19: 24,36 f ; 20: 9)$. Some of these footnotes link with and refer to texts from the Old Testament and they indicate that the readers must have been familiar with it. Again, this tendency is a contrast to other footnotes which indicate the readers' lack of familiarity with Jewry, its customs and milieu.

\subsubsection{Footnotes relating to discussion and summary of events and issues.}

Nineteen footnotes in this category have to do with the numbering of the semeia, the baskets of food, the number of fishes caught and the number of Jesus' appearances after his resurrection. In six of these footnotes, Jesus' antagonists are dealt with negatively. It is also mentioned that these antagonists took offence at Jesus because of his alleged infringement of the Jewish traditions relating to God, the Messiah and the patriarch Abraham. The readers are supposed to know these traditions.

Therefore we conclude that these readers could have been Jews or Jewish proselytes. The narrator wanted them to understand Jesus' actions relating to these traditions. However, this category also furnishes footnotes which suggest that the original readers did not know these traditions!

\subsubsection{Footnotes relating to identifying the characters within the narrative.}

The vast majority of these footnotes - which number thirty-one identify and characterise persons with whom the original readers were not familiar. An analysis of these footnotes furnishes the following results: 
(a) John the Baptist is characterised in terms of Jewish religious traditions from the Old Testament.

(b) Simon Peter is treated as a well-known person and other characters are identified with reference to their relationship with him.

(c) The narrator proceeds from the viewpoint that the readers are familiar with and pay due respect to the way the Jews administer their religious affairs.

(d) It is not known whether the original readers were familiar or not with the enigmatic character(s) known as 'the disciple whom Jesus loved' and 'the one who knew the high priest'. It may well be that the author made use of the literary convention of anonymity or opted for an attitude of humility. If Cleopas (Jn 19: 25) was known to the readers, then the frame of reference of the narrated events must be Jewish and Palestinian.

(e) In conclusion we may state that the footnotes in this category strongly indicate that we should accept that the implied readers had a Jewish theological frame of reference, despite their unfamiliarity with some of the main characters of the narrative.

\subsubsection{Footnotes relating to knowledge of Jesus, the main character, and insight into his thoughts and intentions}

The omnipresence and omniscience of the narrator are very prominent in these footnotes, and is evident in his knowledge of Jesus' hidden thoughts, intentions and emotions. The author's viewpoint (focalisation) is also clearly expressed. As far as this is concerned, it is difficult to establish whether the commentary in the prologue reflects a Hellenistic or Jewish frame of reference. No consensus has yet been reached on this issue.

In one respect these footnotes provide markers for identifying the frame of reference of the readers within the text. This is in respect of three instances in which references are made to the Jewish prophetic traditions and their wisdom literature (viz Jn 12: 16-17; 18: 9 and 19: 28). These footnotes serve as explanations of Jesus' actions and words as given by someone from the innermost circle of the followers of Jesus. Once again, a Jewish basis and undertone are observed.

\subsubsection{Footnotes relating to general theological discussions on events and sayings}

Here we consider Jesus' discourse with Nicodemus and his references to John the Baptist. Jesus is addressed as a Jewish rabbi and John the 
Baptist sees his work of preparing the way for the Messiah in terms of the Isaiah tradition. Jesus is referred to as the Christ (Messiah) of the Jewish tradition, and as king and son of God. Both Hellenistic and Jewish readers would have understood the last two of these appellations, whereas the Christ-title would have appealed to the Jewish reader.

\section{THE JOHANNINE CHURCH - SEEN IN THE MIRROR OF EVENTS WITHIN THE TEXT OF JG}

In concluding this section, we will focus attention on the reader within the text, as typified and characterised in the commentary (footnotes) of the narrator himself.

The textinternal church is an imagined and literary construction encoded for the readers. It forms an image of the ideal, implied reader who is guided and informed by the narrator so that he can respond appropriately to the narrative. The real reader outside the text should also read and understand the text in this way and respond to it as the implied reader was guided to do.

Nothing is said explicitly about the character and identity of the original reader(s) of the first century. This ideal reader is, however, not a faceless entity, for he has a specific identity and possesses a certain prescience and frame of reference which makes the event of communication with the narrator possible. The corporate point of contact between narrator and reader/narratee consists of the historical, social, religious and theological contents of their shared frame of reference.

According to indications given by the footnotes, the identity of the implied reader can be described as follows:

(a) On the one hand, the implied reader is unfamiliar with and stands outside the Jewish-Palestinian world. This can be observed in footnotes which translate Hebrew/Aramaic words and names into Greek, where time and localities are indicated, where Jewish customs are explained, and where some of the explanatory commentaries provide notes on the reminiscences of the disciples and markers of localities.

(b) On the other hand, the remaining footnotes describe readers who are well acquainted with the frame of reference and world of thought of Jewish customs and religious traditions. The contents of the logos concept in the prologue, point to the Jewish, Old Testament and Hellenistic worlds. 
Thus the text of JG mirrors an ambivalent church. Sometimes it is separated from and unfamiliar with the historical, physical and religious milieu of the Jews and Palestine. At other times, it is well acquainted with and involved in the Jewish world of life and thought as well as that of Jewish proselytes.

\section{THE JOHANNINE CHURCH - AN EVENT SEEN THROUGH THE WINDOW OF THE TEXT OF JG}

The idea of a Johannine church/school or of a separate religious community within early Christianity already has a fixed form. On account of the testimonies of the Church Fathers (Ignatius, Polycarp and Papias), Ephesus is accepted as the place of work and sojourns of John and where his community was domiciled. This viewpoint has been maintained for centuries and has been scrutinised by prominent scholars. In their work they have paid attention to the nature and scope of the Johannine church.

Since the sixties of our century, critical reflection has emphasised the methodological aspects of Johannine research. After J Wellhausen, scholars concentrated on the contents of JG so as to gain information on the Johannine school from which and to which this gospel was written. The importance and popularity of this approach can be assessed from the many publications, especially since 1970 . The major ones are those of J M Robinson \& H Koester (1971), W A Meeks (1972), O Cullmann (1975), R Kysar (1975), R A Culpepper (1975), D M Smith (1975), J L Martyn (1979), R E Brown (1979) and F F Segovia (1982).

A common feature of these studies is that they proceed basically from the text of JG as source of their investigations. Other sources have been utilised in elucidating the results of the analyses and for providing historical perspective. These sources are the writings of the Church Fathers and of historians such as Eusebius (Historia Ecclesiastica).

The hermeneutical premise of these analyses is that JG serves as a window through which the events within the Johannine church can be seen and reconstructed.

Judged from the perspective of literary criticism, the above approach is guilty of 'referential fallacy'. This happens whenever an exegete moves without any ado from the world of the text to the historical, socio-cultural and religious context of the actual world to which the world of the text is related (see Van Aarde 1985: 45). This constitutes a 
one-equals-one relationship between the textinternal and the textexternal worlds. Literary critics find this assumption totally unacceptable.

The historical approach used in looking at the Johannine church/ school through the window of the text, also errs by exceeding the limits of the potentialities of a text. In the theory relating to texts, however, the question pertaining to the nature, essence, potentialities and limitations of a text can no longer be ignored.

\section{OR/AND?}

The final question is whether or not these two approaches and their results radically exclude each other. Is the only option open to the researcher to choose between the two?

However, if by one or another legitimate procedure, one is able to reach the real reader in the actual world outside the text by proceeding from the implied reader within the text, then one should alter the title of this paper to read: John's gospel and the Johannine church: A mirror of events within a text AND a window on events within a church.

\subsection{The advisability of placing the conjunction 'and' between the components of the title}

The writer is well aware that some modern scholars insist that New Testament texts are totally a-contextual and that we simply do not know their contexts (see Chatman 1978: 148; Bal 1978; Vorster (1987: 12); and others). According to these scholars, a literary critical paradigm does not aim at addressing the context of the extratextual world. Furthermore, they contend that information about the implied reader is only furnished to guide the real reader in understanding the text. This includes reading the text in an appropriate manner and in actualising its potentialities. These scholars consider that the real reader has to identify with the implied reader and with his response to the text. This is the appeal of the text to any real reader - for both first and twentieth centuries.

We must keep in mind, however, that we have to do with a religio-historical text. Hence, in principle, it should be accepted that the text is aimed at presenting a particular historical, sociological and religious situation to which the real reader is supposed to respond. This can only be done with the aid of the text itself and by the example set by the response of the implied reader. 
When this assumption is not accepted and taken into account, the exegete and reader are guilty of 'affective fallacy'. This takes place when the literary function and intention of the author are ignored or even denied - in which case the potentialities of meaning of the text and its literality are lost to the experience of the reader himself. This is unacceptable, since the author's intention should always be taken into account, especially in religious texts where this aspect is essentially important.

Authors and narrators communicate this intention by means of literary techniques such as style, plot, irony, symbolism, focalisation, characterisation, et cetera (see Jakobson 1960: 353; Chatman 1978: 162ff; Fowler 1982: 155f; Van Luxemburg, Bal \& Weststeijn 1983: 156; Burnett 1985: 91-109; Vorster 1987: 11).

According to this perspective, the potentialities of meaning and function of the text are made actual (concretised) in an interaction between the author, the text and the reader. As far as the intratextual reader is concerned, this inevitably takes place within the context of the narrated world and the frame of reference of the extratextual reader (of the first and twentieth centuries). It also takes place within a particular, concrete situation. In the case of religio-historical texts such as JG, this is an essential feature, namely that the world of the text of necessity refers to and correlates with a particular concrete world and events outside the text.

In principle, therefore, this real world should not and can not be disregarded, solely because the religio-historical text is primarily directed at changing the real world.

In view of this state of affairs, it is possible, to a certain extent, to reconstruct the world outside the text from the textinternal world which is narrated. Therefore, on account of the intention and direction of a religio-historical text such as JG, and because of the implicit correlation between the intra- and extratextual contexts, we must insert 'AND' between the components of the title of this paper.

The above approach places us in the centre of a theory on texts and their pragmatics. This involves the question of the nature and objective of the text itself. In this regard it should be assumed that JG, as a religio-historical text, contains a syntactical and semantic, as well as a pragmatic level and function. This entails further questions relating to the nature and pretention of religious texts. Robert Detweiler (1985: $213-30$ ), who is mainly interested in the process of canonisation of religious texts, points out in his phenomenological investigation that 
such religious texts display seven salient features. As far as our study is concerned, the major characteristic of these features is that these texts possess the right and the power to change the lives of human beings. This means that such texts make an appeal to the intratextual and extratextual readers. The text does something to the intratextual reader in his context. The same happens to the real, extratextual reader in his context.

Hence, religious texts are by no means a-contextual; neither are they neutral or incompetent. Being a religious text, JG had a relevant intentionality towards the implied and the real readers of the first century.

It is then logical and justifiable to assert that there originally existed an implicit correlation between the context and identity of the implied reader within JG AND the context and identity of the readers outside the text of JG. This was a conditio sine qua non for making the text of JG intelligible, relevant and actual for its original real readers. This condition also made it possible that communication could take place and made it meaningful for the original readers to identify with the implied readers of JG and to respond to the text of it.

This correlation between the intra- and extratextual readers is defined as a referential correlation of events of communication within and by the text. Basically this correlation is constituted by the fact that the narrated world of the implied reader is not at all a fictitious world which is directly and illegitimately conveyed to the real world, and accomplished by a secondary process of reconstruction and 'referential fallacy'. On the contrary, this narrated world is the real world of events around the historical Jesus of Nazareth in the Middle-East.

The analyses of footnotes above have shown that the direction of the reference is precisely the opposite, namely from the real world of the Jews and non-Jews inside and outside Palestine to the world of the text. This happens to be the case since the real world of the Christ event formed and functioned as the frame of reference for the narrated world and the implied readers. The narrative's kerugmatic presentation of the events does not change the fact that the world of the text is basically orientated towards an historical reality to which it undoubtedly refers.

Although the narrated world within the text of JG and the real world outside the text do not relate in a one-equals-one order, the original real reader saw in the mirror of the text an image of an ideal, implied reader/church. The narrator, as the author's spokesman, wanted to persuade this real reader to identify with the positive response of the 
ideal reader within the text. This could be attained by reading the text in an appropriate way.

\section{CONCLUSION}

Viewed in this perspective of pragmatics of religio-historical texts and their function of communication, I insert the conjunction 'AND' between the components of the title of this paper. In this way historical and text-immanent methods of exegesis are integrated to a certain extent. I maintain that this is an appropriate means of understanding and reading the text of $\mathrm{JG}$, because the text itself establishes this process. During this process both the implied and the real reader are persuaded to identify positively with the main character, Jesus Christ, by believing in him and by being his helpers (Jn 20: 30-31).

\section{Works consulted}

ABRAMS, MH 1979. How to do things with texts. Partisan Review 46, 566-88.

$\mathrm{BAL}, \mathrm{M}$ 1978. De theorie van vertellen en verhalen, in Inleiding tot de narratologie. Muiderberg: Couthino.

BEARDSLEE, WA 1970. Literary critics of the New Testament. Philadelphia: Fortress Press. BECKER, J 1982. ThR 47, 279-301, 305-47.

BECKER, J 1986. Das Johannesevangelium im Streit der Methoden (1980-84). ThR 51 (1), $1-78$.

BENVENISTE, E 1966. Structure des relations de personne dans le verbe, in Problèmes de linguistique génerale. Paris: Gallimard.

BENVENISTE, E 1970. L'appareil formel de I'enonciation. Language 17, 14-19.

BOOTH, WC 1961. The rhetoric of fiction. Chicago: UCP.

BROWN, RE 1979. The community of the beloved disciple. The life, loves and hates of an individual church in the New Testament times. New York: Paulist Press.

BULTMANN, R 1941. Das Evangelium des Johannes. (KEK 2). Göttingen: Vandenhoeck \& Ruprecht.

BURNETT, F 1985. Prolegomenon to reading Matthew's eschatological discourses: Redundancy and education to the reader in Matthew. Semeia 31, 91-109.

CHATMAN, S 1978. Story and discourse: Narrative fiction and film. Ithaca: Cornell University Press.

CROSSAN, JD 1983. It is written: a structuralist analysis of John 6. Semeia 26, 1-21.

CULLMANN, O 1975. Der johanneische Kreiss, sein Platz im Spätjudentum, in der Jüngerschaft und im Urchristentum. Tübingen: Mohr.

CULPEPPER, RA 1975. The Johannine school hypothesis based on an investigation of the nature of ancient schools. Missoula: Scholars Press.

CULPEPPER, RA 1983. Anatomy of the fourth gospel: A study in literary design. Philadelphia: Fortress Press.

DETWEILER, $R$ 1985. What is a sacred text? Semeia 31, 213-30.

DORNISCH, L 1975. Symbolic systems and the interpretation of Scripture: An introduction to the work of Paul Ricoeur. Semeia 14, 1-21. 
DUNN, JDG 1983. Let John be John, in Stuhlmacher, P (hrsg), Das Evangelium und die Evangelien, 309-339. Tübingen: Mohr.

FISH, S 1980. Is there a text in this class? The authority of interpretive communities. London/Cambridge: Harvard University.

FOWLER, RM 1982. Kinds of literature: An introduction to the theory of genres and modes. Oxford: Clarendon Press.

FOWLER, RM 1985. Who is the reader in reader-response criticism? Semeia 31, 5-23.

GENETTE, G 1980. Narrative discourse: An essay in method. English translation by J E Lewin. Ithaca: Cornell University Press.

GRÄBE, I 1986. Narratologiese ondersoek en eksegese van die boodskap van die evangelies. HTS 42 (1), 151-68.

ISER, $W$ 1974. The implied reader: Patterns of communication in prose fiction from Bunyan to Beckett. Baltimore: John Hopkins University Press.

ISER, W 1978. The act of reading: A theory of aesthetic response. Baltimore: John Hopkins University Press.

JAKOBSON, R. 1960. Concluding statement: Linguistics and poetics, in Sebeok, K (ed), Style in language. Cambridge: MIT Press.

KRIEGER, M 1964. A window to criticism: Shakespeare's sonnets and modern poetics. Princeton: Princeton University Press.

KYSAR, R 1975. The fourth evangelist and his gospel: An examination of contemporary scholarship. Minneapolis: Augsburg Publishing House.

LATEGAN, BC 1984. Current issues in the hermeneutical debate. Neotestamentica 18, $1-17$.

MARTYN, JL 1979. Glimpses into the history of the Johannine community, in The gospel of John in christian history: Essays for interpretation, 90-121. New York: Paulist Press.

MEEKS, WA 1972. The man from heaven in Johannine sectarism. JBL 91, 44-72.

NEIRYNCK, F \& Van Segbroeck, F 1984. Libri Novi Testamenti: Johannes. ETL 60 (2-3), $211-17$.

ONUKI, T 1982. Zur literatur/soziologische Analyse des Johannesevangeliums - auf dem Wege zur Methodenintegration. Annual of the Japanese Biblical Institute (AJBI) 8 , $162-216$.

O'ROURKE, JJ 1979. Asides in the gospel of John. NovTest 21, 210-19.

PETERSEN, NR 1978. Literary criticism for New Testament critics. Philadelphia: Fortress Press.

PHILLIPS, GA 1983. This is a hard saying. Who can be listener to it? Creating a reader in John 6. Semeia 26, 23-56.

PRINCE, G 1971. On readers and listeners in narratives. Neophilologus 55, 117-22.

RABINOWITZ, PJ 1977. Truth in fiction: A reexamination of audiences. Critical Inquiry 4, $121-41$.

RICOEUR, P 1971. What is text? Explanation and interpretation, in Leroux, S(ed), Pouguoi la philosophie? Montreal: Les Editions de Sainte-Marie.

RIMMON-KEGAN, S 1983. Narrative fiction: Contemporary poetics. London: Methuen.

ROBINSON, JM \& KOESTER, H (eds) 1971. Trajectories through early Christianity. Philadelphia: Fortress Press.

SEGERS, $\mathrm{R}$ 1980. Het lezen van literatuur: Een inleiding tot een nieuwe literatuurbenadering. Baarn: Ambo.

SEGOVIA, FF 1982. The structure, Tendenz and Sitz im Leben of John 13: 31-14: 31. JBL 104 (3), 471-93.

SMITH, DM 1974-75. Johannine Christianity: Some reflections on its character and delineation. NTS 21, 222-48.

STERNBERG, M 1978. Expositional modes and temporal ordering in fiction. Baltimore/ London: John Hopkins University Press.

SULEIMAN, SR 1980. Introduction: Varieties of audience-orientated criticism, in Sulei- 
man, SR \& Crosman, I (eds), The reader in the text: Essays on audience and interpretation, 3-45. Princeton: Princeton University Press.

TENNEY, MC 1960. The footnotes in John's gospel. Bibliotheca Sacra 350-64.

THYEN, H 1960. Aus der Literatur zum Johannesevangelium. ThR NF 44, 338-59.

THYEN, H 1974-75. Aus der Literatur zum Johannesevangelium. ThR NF 39, 53-69.

TODOROV, T 1972. sv 'Temps'. Dictionaire encyclopédique des sciences du language. Paris: Seuil.

VAN AARDE, AG 1985. Die outeursvraagstuk van die Johannesevangelie met die oog op interpretasie of resepsie. Skrif en Kerk 6, 45-62.

VAN LUXEMBURG, J \& BAL, M \& WESTSTEIJN, WG 1983. Inleiding in de Literatuurwetenschap. Muiderberg: Couthino.

VORSTER, WS 1984. Meaning and reference. The parables of Jesus in Mk 4, in Lategan, BC \& Vorster, WS, Text and reality. Aspects of reference in Biblical texts. Philadelphia: Fortress Press.

VORSTER, WS 1985. Der Ort der Gattung Evangelium in der Literaturgeschichte. $V u F 29$, $2-25$.

VORSTER, WS (1987). The reader in the text: Reflections on the interpretation of the New Testament. (Forthcoming in Semeia). 